\title{
MINERALIZAÇÕES AURIFFERAS NOS GRUPOS SERRA DO ITABERABA E SÃO ROQUE ENTRE GUARULHOS E SANTA ISABEL-SP
}

\author{
P.Beljavskis ${ }^{1}$ \\ C.Juliani ${ }^{2}$ \\ G.M.Garda ${ }^{3}$ \\ H.D.Schorscher ${ }^{2}$
}

O Grupo Serra do Itaberaba na região Guarulhos-Santa Isabel é constituido por seqüência vulcano-sedimentar intensamente polideformada e polimetamorfisada (predomina regionalmente a fácies anfibolito médio à dos xistos verdes). A idade da seqüência tem sido considerada como proterozóica média a inferior.

Rochas metabasfticas de composição toleftica do tipo MORB predominam amplamente dentre as vulcânicas e subvulcânicas, ocorrendo de modo subordinado metandesitos, metadacitos e metariólitos, além de rochas metavulcanoclásticas básicas a intermediárias. Entre os metassedimentos terrígenos predominam os derivados de pelitos, posicionados geralmente sobre e localmente sob as rochas metavulcânicas. Rochas quartziticas também se destacam em partes da seqùềncia. Em menor volume afloram rochas cálcio-silicáticas, metapelitos grafitosos, ferruginosos e quartzosos e formações ferrfferas. De expressão local tem-se ainda metaexalitos vulcanogênicos, como metacherts, turmalinitos e metapelitos e metavulcanoclásticas com disseminações e leitos de sulfetos.

Sobre este conjunto de natureza vulcano-sedimentar, encontram-se espessos pacotes de metapelitos manganesfferos-ferruginosos com lentes de rochas carbonáticas, por sua vez

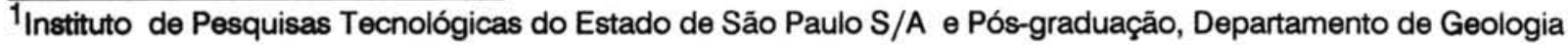
Econômica e Geofísica Aplicada, Instituto de Geociências, USP.

${ }^{2}$ Departamento de Mineralogia e Petrologia, Instituto de Geociências, USP.

3Pós-graduação, Departamento de Mineralogia e Petrologia, Instituto de Geociências, USP.
} 
capeados por metapelitos peraluminosos.

O Grupo São Roque aflora parcialmente na região, colocado em contato e sobre o Grupo Serra do Itaberaba através de falhamentos de empurrão e transcorrentes.

Inúmeras ocorrências de ouro foram reconhecidas na região, destacando-se, pela distribuição e teores, as das áreas Tapera Grande e Pedra Branca. Preliminarmente estas mineralizações foram agrupadas, com base em seus característicos geológicos, petrográficos e geoquímicos em:

a) Tipo predominantemente singenético, associado às rochas metavulcanoclásticas básicas e intermediárias e aos metaexalitos (metachert com sulfetos e turmalinitos).

Este foi identificado somente no Grupo Serra do Itaberaba. Os teores de ouro variam entre 0,06-11,0 ppm (metavulcanoclásticas) e 1,5-13,0 ppm (metaexalitos). Neste tipo foram verfficadas correlaçőes ouro-prata-tungstênio-cobre, baixos teores de chumbo e zinco e estão praticamente ausentes o arsênio, o antimônio e o molibdênio.

As rochas mineralizadas, relativamente às suas equivalentes não mineralizadas, mostram empobrecimentos em $\mathrm{MgO}, \mathrm{CaO}, \mathrm{K}_{2} \mathrm{O}$ e $\mathrm{Na}_{2} \mathrm{O}$, acompanhados de leve enriquecimento em $\mathrm{SiO}_{2}$. Rochas basálticas e vulcanoclásticas com alterações hidrotermais-metassomáticas em parte semelhantes às não mineralizadas são comuns na Serra do Itaberaba. A ausência de zonas de alterações nos metassedimentos superpostos e a distribuição dos corpos na interface de metabasaltos-metapelitos são indicativas da origem singenética.

O ouro associa-se à pirrotita-pirita e subordinadamente à calcopirita, onde ocorre esséncialmente em granulação muito fina, não identificável opticamente.

b) Tipo epigenético, com veios de quartzo sulfetados, superimposto ao anterior ou associado às zonas de cisalhamento.

Este foi constatado em ambos Grupos. No tipo epigenético do Grupo Serra do Itaberaba os teores de ouro variam entre 0,1 e 11,2 ppm, alcançando, em amostragens pontuais até $25,6 \mathrm{ppm}$. A prata tem valor máximo de $1,8 \mathrm{ppm}$. Os teores de cobre, chumbo, zinco e prata são relativamente mais elevados que no tipo anterior e foram verificadas correlações ouro-prata-cobrechumbo-zinco. Molibdênio e antimônio também ocorrem, mas com teores baixos e o tungstênio e o arsênio estão praticamente ausentes. Estas mineralizações associam-se comumente às rochas metavulcanoclásticas (contendo traços de scheelita e de ouro) e metapelitos com intercalações de formações ferrfferas e de metachert intensamente cisalhados. Mais raramente ocorrem como veios de quartzo em metapelitos não cisalhados. No primeiro conjunto podem ser distinguidas diversas 
gerações de veios de quartzo, variavelmente cisalhados.

O ouro apresenta-se sob a forma predominantemente livre, tem granulação grossa e está associado aos sulfetos de cobre (calcopirita e covelita) ou ao quartzo.

As ocorrências de ouro no Grupo São Roque na região estudada constituem pequenos veios de quartzo sulfetados encaixados em filitos cisalhados. Tem, caracteristicamente, elevados teores de arsênio, chumbo, zinco, cobre, molibdênio e prata, além de bismuto em pequenas quantidades; antimônio e tungstênio estão praticamente ausentes.

Ao nivel atual do conhecimento parece ser possivel a distinção química entre estes diferentes tipos de mineralizações e entre as epigenéticas dos grupos Serra do Itaberaba e São Roque. Estes aspectos serão melhor definidos através dos estudos de inclusões fluidas, isótopos estáveis e dados petroquímicos que serão desenvolvidos futuramente. 